Article

\title{
Comparative Study of Chloride and Fluoride Induced Aluminum Pad Corrosion in Wire-Bonded Device Packaging Assembly
}

\author{
Goutham Issac Ashok Kumar, Alexander Lambert, Joshua Caperton, Muthappan Asokan, William Yi \\ and Oliver Chyan *
}

check for updates

Citation: Ashok Kumar, G.I.; Lambert, A.; Caperton, J.; Asokan, M.; Yi, W.; Chyan, O. Comparative Study of Chloride and Fluoride Induced Aluminum Pad Corrosion in Wire-Bonded Device Packaging Assembly. Corros. Mater. Degrad. 2021, 2,447-460. https://doi.org/10.3390/ cmd 2030023

Academic Editor: Angeliki G. Lekatou

Received: 21 June 2021

Accepted: 5 August 2021

Published: 11 August 2021

Publisher's Note: MDPI stays neutral with regard to jurisdictional claims in published maps and institutional affiliations.

Copyright: (c) 2021 by the authors. Licensee MDPI, Basel, Switzerland. This article is an open access article distributed under the terms and conditions of the Creative Commons Attribution (CC BY) license (https:// creativecommons.org/licenses/by/ $4.0 /)$.
Interfacial Electrochemistry and Materials Research Lab, University of North Texas, Denton, TX 76203, USA; gouthamissacashokkumar@my.unt.edu (G.I.A.K.); alambert287@gmail.com (A.L.);

JoshuaCaperton2@my.unt.edu (J.C.); muthappanasokan@gmail.com (M.A.); williamyi@my.unt.edu (W.Y.)

* Correspondence: chyan@unt.edu; Tel.: +1-940-565-3463

\begin{abstract}
The introduction of copper as wire bonding material brings about a new challenge of aluminum bond pad bimetallic corrosion at the copper/aluminum galvanic interface. Aluminum is well known to undergo pitting corrosion under halide-contaminated environments, even in slightly acidic conditions. This paper aims to study the corrosion morphology and progression of aluminum influenced by different halide contaminations in the presence and absence of galvanic contact with copper. We used a new corrosion characterization platform of the micropattern corrosion screening to simulate the copper wire bonding on the aluminum bond pad. The corrosion screening data and subsequent SEM-EDX analyses showed a striking difference in morphology and progression between chloride-induced and fluoride-induced aluminum corrosion. The corrosion products formed play a vital role in the resulting morphology and in sustaining further aluminum corrosion.
\end{abstract}

Keywords: wire-bonded device; halide contaminant; Al pad corrosion; corrosion inhibitor

\section{Introduction}

Our day-to-day life extensively uses wire-bonded electronic devices (WBDs) for various applications in medicine, communication, transportation, and so on. The cost-effective nature of wire-bonded devices rises due to their flexible interconnect assembly technology. Copper $(\mathrm{Cu})$ has replaced gold $(\mathrm{Au})$ as wire bonder material due to its several advantages, such as lower cost, higher Young's modulus, and lower resistivity [1]. However, Cu wiring has introduced reliability issues, such as corrosion of the aluminum (Al) bond pad, leading to WBD failure. According to reports, halides such as chloride $\left(\mathrm{Cl}^{-}\right)$and fluoride $\left(\mathrm{F}^{-}\right)$can corrode $\mathrm{Al}$ even at low ppm concentrations, causing the $\mathrm{Cu}$ wire to lift off from the $\mathrm{Al}$ pad [2-5]. The $\mathrm{Cl}^{-}$contaminant in packaging is usually from epoxy molding compounds (EMCs), which can initiate corrosion in the presence of moisture. $\mathrm{F}^{-}$contaminants mainly come from plasma processes, leading to non-stick-on-pad (NSOP) reliability issues [6].

The Al surface can undergo severe pitting due to halide interaction, resulting in cracks and dendrites. The commonly accepted mechanism is that the halide ion attacks the Al surface by penetrating the passivating oxide layer, causing continuous pitting due to the localized cells on the surface [7-9]. Since the introduction of thin-film Al in microelectronics, wide-scale investigation of the corrosion properties in thin-film structures has been ongoing. The corrosion of $\mathrm{Cu} / \mathrm{Al}(\mathrm{Cu}$ bimetallic contact with $\mathrm{Al}) \mathrm{WBD}$ in $\mathrm{Cl}^{-}$ gained more attention in the past decade because they are the most common contaminants in the microelectronic manufacturing environment [10-12]. However, the exact mechanism of how the $\mathrm{F}^{-}$corrosion proceeds have not yet been reported and studied in detail. In addition, systematic exploration of the halide corrosion in Al thin film in the presence of bimetallic contact with $\mathrm{Cu}$ is absent. 
Previous investigations reported that the intermetallic compounds (IMCs) formed between $\mathrm{Cu}$ and $\mathrm{Al}$ were the main reason for the failure of WBD under moisture and halide contaminants [13-15]. However, the severity of Al corrosion depends on several factors, such as halide concentration, $\mathrm{pH}$, nature of the corroding cell, bimetallic contacts, and so on. Halides, being the most common contaminants found in the packaging line, poses a significant threat to the reliability of $\mathrm{Al}$ bond pads even in slightly acidic conditions. The approach for this study focuses on the peripheral $\mathrm{Cu} / \mathrm{Al}$ bimetallic contact rather than the buried IMCs. The corrosion mechanism of the $\mathrm{Cu} / \mathrm{Al}$ bimetallic contact in the periphery of WBD due to $\mathrm{Cl}^{-}$contaminant was reported before by Ross et al. [16]. This study focuses on the corrosion morphology and proposes $\mathrm{F}^{-}$contaminant mechanism related to WBD and compares them with $\mathrm{Cl}^{-}$contaminant corrosion.

This research investigates the corrosion of $\mathrm{Al}$ (with $0.5 \mathrm{wt} \% \mathrm{Cu}$ ) immersed in dilute $\mathrm{Cl}^{-}$and $\mathrm{F}^{-}$solutions (ppm level) at a slightly acidic $\mathrm{pH}(\mathrm{pH}=5)$. $\mathrm{pH} 5$ was chosen for corrosion screening to simulate the slightly acidic nature of EMCs with moisture. A new in situ corrosion study platform termed micropattern immersion corrosion screening was developed to study the corrosion progression in real time. The micropattern was created by sputtering $\mathrm{Cu}$ microdots on $\mathrm{Al}$ to simulate the $\mathrm{Cu}$ wire on the $\mathrm{Al}$ bond pad interface serving as a quick and cost-effective way of studying different corrosion conditions and corrosion inhibitors without the actual usage of a real WBD [17]. In situ corrosion progression insights lead to the development of the corrosion mechanism and corrosion inhibition strategies. Immersion screening metrology may have a different kinetic preference mechanism from actual industrial corrosion testing, such as HAST (highly accelerated stress testing), usually performed in molded encapsulated devices. This testing metrology exposes the Al surface to a more severe corrosive condition than the industry testing due to the complete immersion of devices in $100 \%$ moisture with halide contaminants without ion traps typically present in the EMCs to reduce corrosion contaminant delivery to the bond pad [18].

This article discusses the difference in the corrosion progression of $\mathrm{Al}$ thin film in the presence and absence of $\mathrm{Cu}$ bimetallic contact immersed in $\mathrm{Cl}^{-}$and $\mathrm{F}^{-}$environments. In situ monitoring of the corrosion provided crucial understandings of the different mechanisms between the $\mathrm{Cl}^{-}$and $\mathrm{F}^{-}$environment. This mechanistic understanding holds the key to deciphering the corrosion cycle, mitigating different $\mathrm{Al}$ pad corrosion types, and preventing the $\mathrm{Cu}$ wire lift-off.

\section{Materials and Methods}

The $\mathrm{Al}$ samples mentioned in this study refer to $\mathrm{Al}$ alloyed with $0.5 \mathrm{wt} \% \mathrm{Cu}$. Corrosion screening was carried out by studying the real-time progression of corrosion under the microscope. The detailed procedures for the micropattern screening technique were described in this publication [17]. The micropatterns used in this study are shown in the Figure 1 schematic. The micropatterns were created by sputtering $130 \mu \mathrm{m}$ diameter $\mathrm{Cu}$ microdots onto an $\mathrm{Al}$ (with $0.5 \mathrm{wt} \% \mathrm{Cu}$ ) substrate to imitate the $\mathrm{Cu}$ wire bonding to the $\mathrm{Al}$ bond pad scenario. The thickness of the dots ranged from 50 to $500 \mathrm{~nm}$. A Nikon LV-150 optical microscope was used for monitoring and recording the corrosion progression. All chemicals were reagent grade and used as obtained from Merck. The dilute halide solutions were made by a series of dilutions from a $1000 \mathrm{ppm}$ stock solution of $\mathrm{NaCl}$ and $\mathrm{NaF}$, respectively, for $\mathrm{Cl}^{-}$and $\mathrm{F}^{-}$solutions. Ultrapure water from Millipore Sigma (resistivity, $18.1 \mathrm{M} \Omega$, Burlington, VT, USA) was used in making solutions, rinsing samples, and performing dilutions. All $\mathrm{pH}$ adjustments were made using $\mathrm{H}_{2} \mathrm{SO}_{4}$ and $\mathrm{NaOH}$ (both reagent grades from Merck, Burlington, NJ, USA). All samples were rinsed with UPW before surface analysis. EM-EDX measurements of corroded samples were obtained from FEI Quanta ESEM scanning electron microscopes (Hillsboro, OR, USA) to study surface products and surface morphology. The gas evolution during corrosion was investigated by the method of headspace chromatography using a Thermo Finnigan gas chromatograph-mass spectrometer (GC-MS, Waltham, MA, USA). The WBD devices were immersed in $\mathrm{Cl}^{-}$and $\mathrm{F}^{-}$conditions separately in a silicone-sealed flask for more than $24 \mathrm{~h}$, 
and the headspace gas was transferred to a GC-MS analyzer for composition identification. Potentiodynamic polarization was carried out using a CHI 760D potentiostat (Austin, TX, USA) in a three-electrode system ( $\mathrm{Al}$ as the working electrode). Electrochemical studies were carried out in samples with a controlled area of $0.3 \mathrm{~cm}^{2}$ exposure. The galvanic coupling current was measured using two electrodes $(\mathrm{Cu}$ and $\mathrm{Al})$ immersed in the solution and electrically connected to a Keithley 2400 source meter (Solon, OH, USA). The chemical composition of the surface products was investigated using PHI 5000 VersaProbe Scanning XPS (Chanhassen, MN, USA).

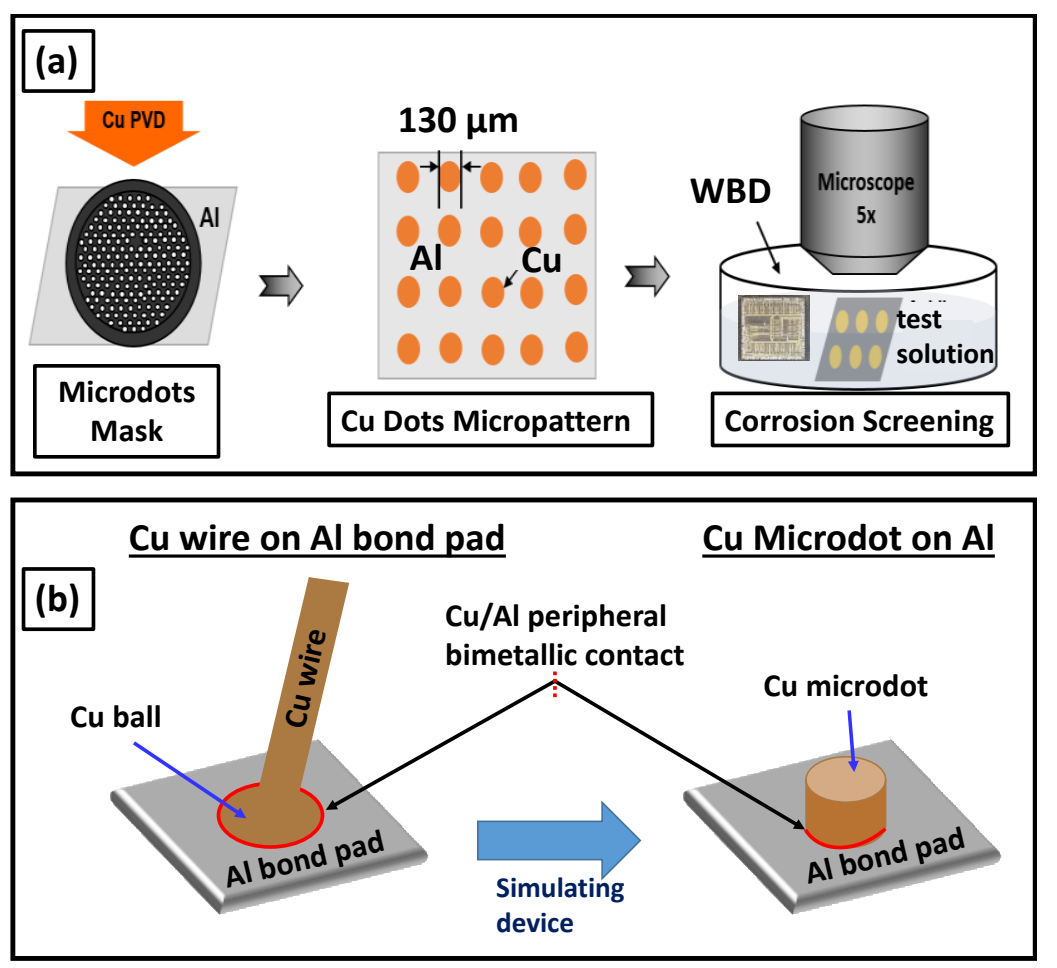

Figure 1. (a) Schematic representation of the immersion micropattern corrosion screening metrology and (b) micropattern sample peripheral bimetallic contact created to simulate the effect of $\mathrm{Cu}$ wire on the Al bond pad.

\section{Results and Discussion}

\subsection{Halide-Induced Corrosion on Blanket Al in the Absence of Cu Bimetallic Contact}

Figure 2 shows the corrosion morphology of blanket $\mathrm{Al}$ substrates immersed in solutions of $5 \mathrm{ppm} \mathrm{Cl}^{-}$and $5 \mathrm{ppm} \mathrm{F}^{-}$at $\mathrm{pH}$. In Figure 2b, surface roughening was observed on the $\mathrm{Al}$ substrate with minor pitting after $24 \mathrm{~h}$ immersion of $\mathrm{Al}$ in $5 \mathrm{ppm}$ $\mathrm{Cl}^{-}$solution at $\mathrm{pH}$ 5. The corrosion progressed with major surface roughening and minor pitting with very little or no dendrite formation. Most of the $\mathrm{Al}$ surface remained unchanged in $\mathrm{Cl}^{-}$solution, visible from the left region in Figure $2 \mathrm{~b}$ with minor pitting. In contrast, $\mathrm{Al}$ was corroded more readily in the presence of an $\mathrm{F}^{-}$environment $\left(5 \mathrm{ppm} \mathrm{F}^{-}\right.$, $\mathrm{pH}$ 5) with two giant pits forming on either end of the $\mathrm{Al}$ surface, as shown in Figure 2c. Closer investigation in the center region of the $\mathrm{Al}$ surface showed extensive $\mathrm{F}^{-}$-induced corrosion pits. Visual inspection of the $\mathrm{Al}$ surface indicates that the $\mathrm{F}^{-}$condition had much more aggressive corrosion than the $\mathrm{Cl}^{-}$condition. $\mathrm{Al}$ was heavily corroded in $\mathrm{F}^{-}$ solution with complete pitting all over the sample with no visible gas evolution or dendrite corrosion. The differences in corrosion morphology induced by $\mathrm{F}^{-}$vs. $\mathrm{Cl}$ suggest that two halides have different $\mathrm{Al}(\mathrm{Al}+0.5 \% \mathrm{Cu})$ corrosion attacking mechanisms. 

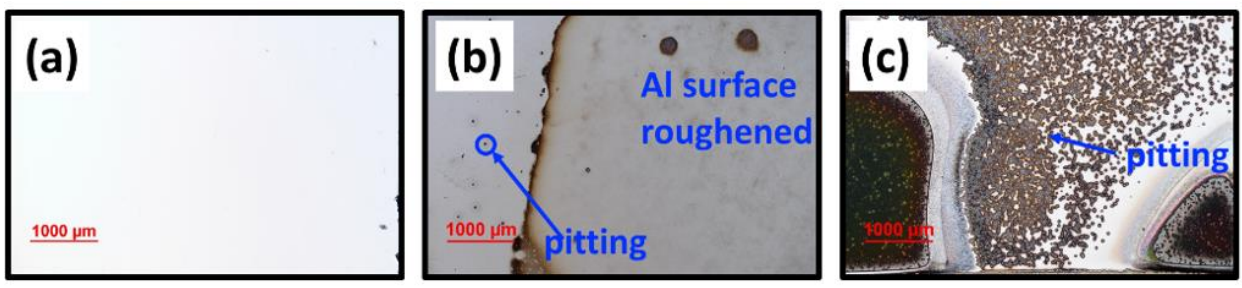

Figure 2. Corrosion screening of blanket Al samples. (a) As prepared before immersion. (b) Immersed in 5 ppm $\mathrm{Cl}^{-}$at $\mathrm{pH} 5$ for $24 \mathrm{~h}$. (c) Immersed in $5 \mathrm{ppm} \mathrm{F}^{-}$at $\mathrm{pH} 5$ for $24 \mathrm{~h}$.

\subsubsection{SEM and EDS Investigation of the Corroded Blanket Al Samples}

The SEM analyses of the corroded $\mathrm{Al}$ samples further corroborated the surface morphology difference after $24 \mathrm{~h}$ of corrosion. As shown in Figure 3, the $\mathrm{F}^{-}$corrosion was characterized by extensive pitting (Figure $3 \mathrm{~b}$ inset) all over the Al sample, whereas the $\mathrm{Cl}^{-}$sample showed only surface roughening after $24 \mathrm{~h}$ with very few pitting spots. SEM imaging of the $\mathrm{F}^{-}$-corroded sample on the pitting shows mud crack morphology on the $\mathrm{Al}$ surface with additional surface precipitates (Figure 3b). EDX analysis on the mud crack region and surface precipitates revealed an $\mathrm{F}^{-}$signal on the sample, indicating the presence of Al-F surface products. The area between the mud crack islands showed minimal $\mathrm{Al}$ and $\mathrm{O}$ signals due to the extensive $\mathrm{Al}$ corrosion that reached the underlying $\mathrm{Si}$ substrate.

Table 1. EDS data for spots numbered in the SEM images in Figure 3.

\begin{tabular}{|c|c|c|c|c|c|c|c|}
\hline $\begin{array}{l}\text { Figure } \\
\text { Number }\end{array}$ & $\begin{array}{l}\text { EDX Spot } \\
\text { Number }\end{array}$ & Area Description & Al Atomic \% & O Atomic \% & $\mathrm{Cl}$ Atomic \% & F Atomic $\%$ & Si Atomic \% \\
\hline $5 a$. & 1 & $\mathrm{Al}$ surface & 94.9 & 5.0 & - & - & 0.0 \\
\hline $5 a$. & 2 & $\begin{array}{l}\mathrm{Cl}^{-}-\text {mud crack } \\
\text { island }\end{array}$ & 45.8 & 48.9 & - & - & 0.0 \\
\hline $5 b$. & 5 & $\begin{array}{l}\mathrm{F}^{-} \text {-surface } \\
\text { precipitate }\end{array}$ & 36.5 & 57.0 & - & 6.5 & 0.0 \\
\hline $5 b$. & 3 & $\begin{array}{c}\mathrm{F}^{-}-\text {mud crack } \\
\text { island }\end{array}$ & 38.0 & 46.5 & - & 15.5 & 0.0 \\
\hline $5 b$. & 4 & $\begin{array}{c}\mathrm{F}^{-} \text {- crack region } \\
\text { between two } \\
\text { islands }\end{array}$ & 13.7 & 17.4 & - & 0.5 & 67.4 \\
\hline
\end{tabular}
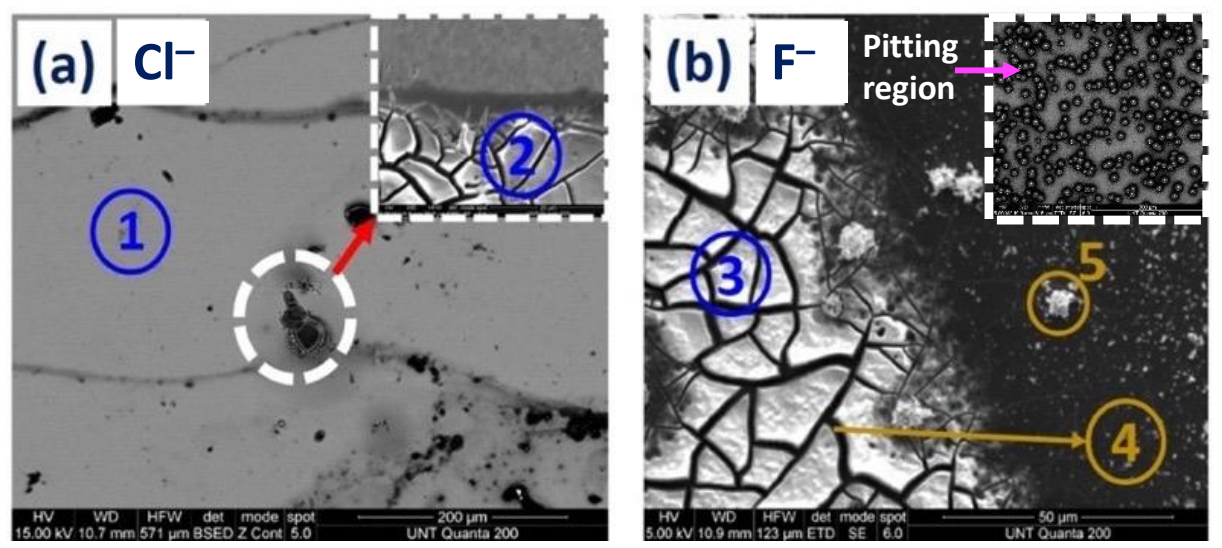

Figure 3. SEM analysis of corroded $\mathrm{Al}$ surface. (a) Al surface after $24 \mathrm{~h}$ immersion in $5 \mathrm{ppm} \mathrm{Cl}^{-}$at $\mathrm{pH}$ 5. Inset (white dotted line): Close-in view of mud crack in $\mathrm{Cl}^{-}$-induced corrosion. (b) $\mathrm{Al}$ surface after $24 \mathrm{~h}$ immersion in $5 \mathrm{ppm} \mathrm{F}^{-}$at $\mathrm{pH}$ 5-close-in view of mud cracks formed in $\mathrm{F}^{-}$-induced corrosion. Inset (white dotted line): Close-in view of the pitting region. Note: EDX analyzed the numbered cycle areas; results are listed in Table 1. 
The $\mathrm{Cl}^{-}$sample showed no extensive pitting or widespread mud crack corrosion morphology, indicating a slow uptake of $\mathrm{Cl}^{-}$ions by the $\mathrm{Al}$ oxide surface. Further zoomedin inspection of the pitting area revealed mud crack corrosion morphology but on a much smaller scale. EDX analysis on the corroded (surface roughened) area and mud crack region revealed the absence of a $\mathrm{Cl}^{-}$signal on the $\mathrm{Al}$ substrate, implying $\mathrm{Al}-\mathrm{Cl}$ surface products' absence. The presence of surface products in $\mathrm{F}^{-}$supports the assertion of having different corrosion attacking mechanisms and different corrosion products in comparison with $\mathrm{Cl}^{-}$. The corroded Al EDX characterization and its elemental composition result are shown in Table 1.

\subsubsection{Electrochemical Characterization Studies}

The Tafel plot analysis observed a similar corrosion trend as the above-mentioned corrosion screening on the blanket Al. As shown in Figure 4, the corrosion potential of Al in 5 ppm $\mathrm{F}^{-}$solution $\left(E_{\text {corr }}=-0.62 \mathrm{~V}\right)$ was considerably more negative than the corrosion potential in $5 \mathrm{ppm} \mathrm{Cl}^{-}$solution $\left(E_{\mathrm{corr}}=-0.37 \mathrm{~V}\right)$. In addition, the corrosion current density of $\mathrm{Al}$ in $\mathrm{F}^{-}$solution $\left(J_{\text {corr }}=16.9 \mathrm{nA} / \mathrm{cm}^{2}\right)$ was close to 10 times higher than in $\mathrm{Cl}^{-}$solution $\left(J_{\text {corr }}=1.8 \mathrm{nA} / \mathrm{cm}^{2}\right)$. Therefore, the observed Tafel data supported the assertion that $\mathrm{F}^{-}$ ions can readily break down the passivation $\mathrm{Al}_{2} \mathrm{O}_{3}$ layer to result in significant pitting corrosion on the $\mathrm{Al}$ surface (see Figure 2c). In comparison, it is less thermodynamically favorable for $\mathrm{Cl}^{-}$ions to break the passive $\mathrm{Al}_{2} \mathrm{O}_{3}$ layer, resulting in less corrosion observed on the Al substrate.

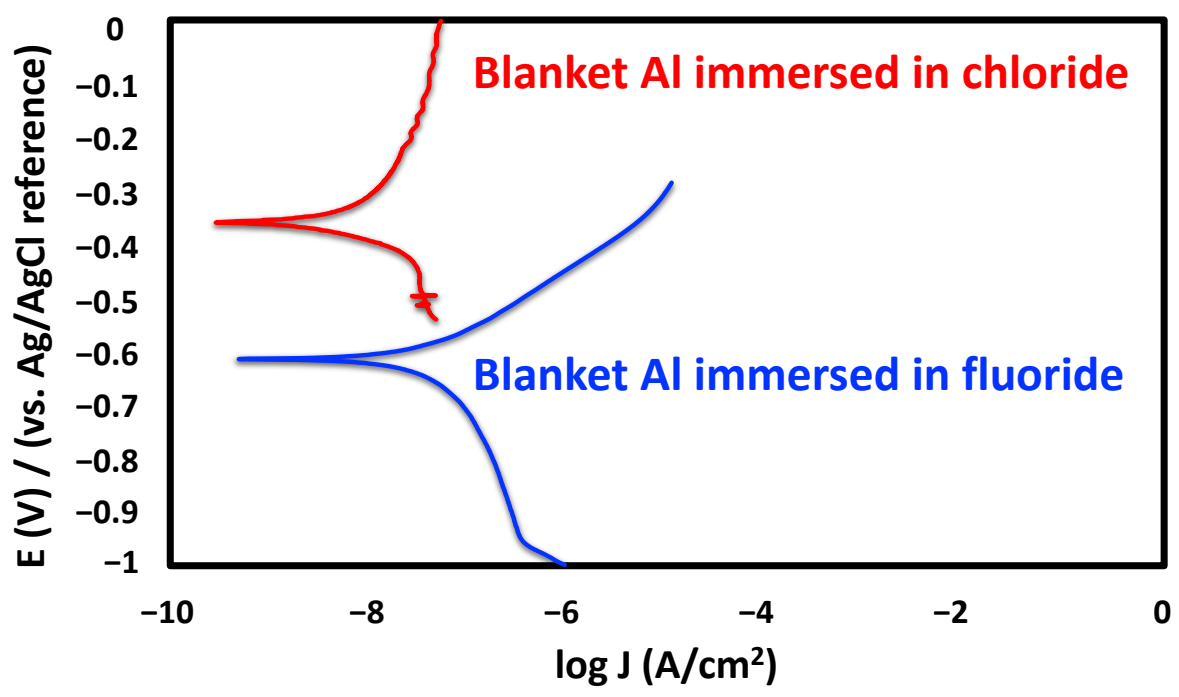

Figure 4. Tafel plot analysis of $\mathrm{Al}$ without bimetallic contact in $\mathrm{Cl}^{-}$and $\mathrm{F}^{-}$containing solutions (5 ppm, pH 5). The scan rate used is $0.001 \mathrm{~V} / \mathrm{s}$.

Next, the galvanic corrosion currents were measured, as shown in Figure 5, by the galvanic coupling of $\mathrm{Cu}$ and $\mathrm{Al}$ electrodes while immersed in $\mathrm{Cl}^{-}$or $\mathrm{F}^{-}$solutions. In this $\mathrm{Cu} / \mathrm{Al}$ couple, the $\mathrm{Cu}$ acted as the cathode and $\mathrm{Al}$ as the anode. The $\mathrm{Cu} / \mathrm{Al}$ galvanic couple immersed in $5 \mathrm{ppm} \mathrm{F}^{-}$solution showed the Al corrosion current increasing to near $4 \mu \mathrm{A}$ in about $20 \mathrm{~min}$. The galvanic couple immersed in $\mathrm{F}^{-}$solution for $60 \mathrm{~min}$ showed an average galvanic coupling current of ca. $3 \mu \mathrm{A}$. Contrastingly, the galvanic couple immersed in $5 \mathrm{ppm} \mathrm{Cl}^{-}$solution showed the onset of corrosion only after $5 \mathrm{~min}$. The observed galvanic current was around $0.7 \mu \mathrm{A}$, almost four times lesser than the observed current in $\mathrm{F}^{-}$solution. The galvanic corrosion current measurement of the $\mathrm{Cu} / \mathrm{Al}$ couple in $\mathrm{F}^{-}$ solution displayed the ready breakdown of passivating $\mathrm{Al}$ oxide in comparison with $\mathrm{Cl}^{-}$ solution similar to the observed Al Tafel plot analysis for blanket Al samples. 


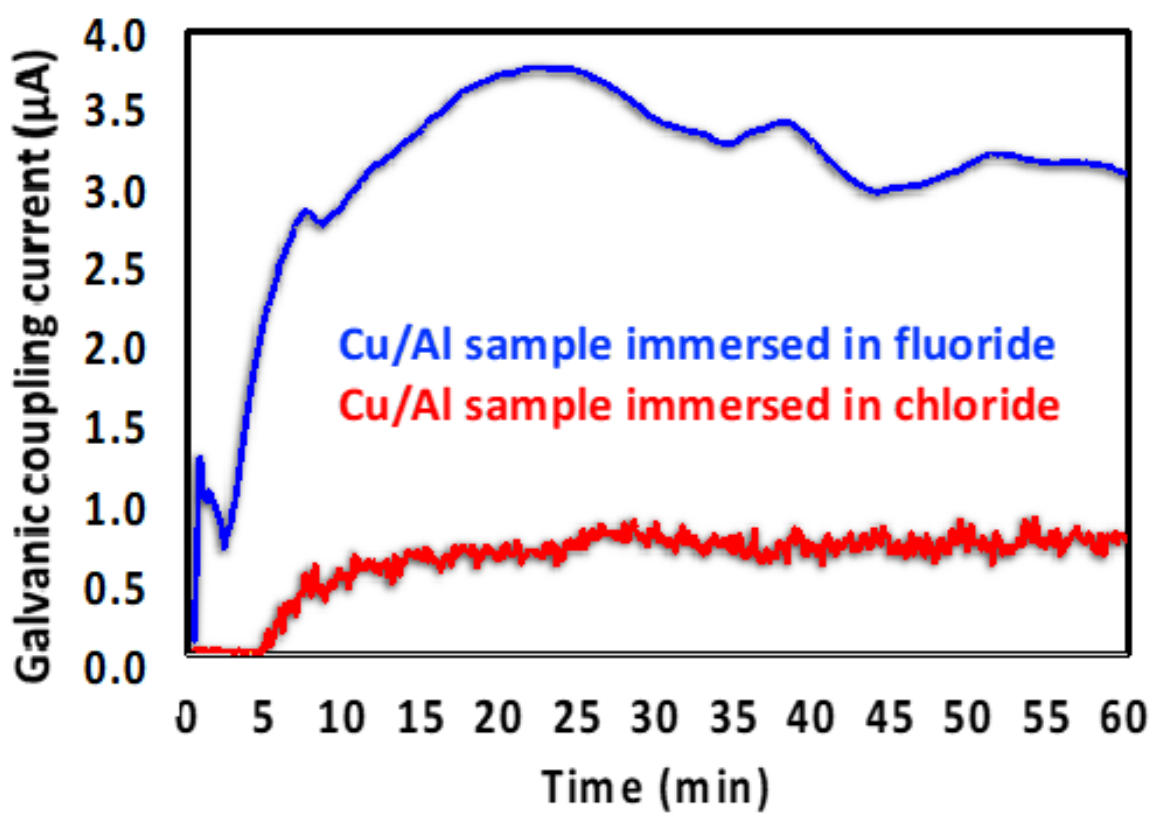

Figure 5. Galvanic coupling current for $\mathrm{Cu}-\mathrm{Al}$ couple immersed in $5 \mathrm{ppm} \mathrm{Cl}^{-}$and $5 \mathrm{ppm} \mathrm{F}^{-}$solutions at $\mathrm{pH} 5$.

\subsection{Halide-Induced Corrosion of Al with Bimetallic Contact to $\mathrm{Cu}$}

The $\mathrm{Al}$ corrosion under the influence of $\mathrm{Cu} / \mathrm{Al}$ bimetallic contact was studied using micropattern samples to simulate the real-life $\mathrm{Cu}$ wire-bonded device situation. As shown in Figure 1, the standing $\mathrm{Cu}$ microdots represent the $\mathrm{Cu}$ bonding wires, which cover the $\mathrm{Al}$ surface to simulate $\mathrm{Al}$ bonding pads. Solutions of $5 \mathrm{ppm} \mathrm{Cl}^{-}$and $5 \mathrm{ppm} \mathrm{F}^{-}$were used at $\mathrm{pH} 5$ to study $\mathrm{Al}$ corrosion in a bimetallic contact situation similar to that shown in Figure 2. As shown in Figure 6, the Al corrosion progression was starkly different with the presence and absence of a peripheral $\mathrm{Cu}$ bimetallic contact. In the absence of peripheral $\mathrm{Cu}$ bimetal contact (see Figure $2 \mathrm{~b}$ ), in a $5 \mathrm{ppm} \mathrm{Cl}^{-}$solution at $\mathrm{pH} 5, \mathrm{Al}$ showed minor corrosion, and the corrosion rate was much slower. However, the presence of $\mathrm{Cu}$ bimetallic contacts made the corrosion of the Al layer more aggressive, accompanied by immediate gas escape at the corrosion site. This gas was later analyzed and confirmed as hydrogen $\left(\mathrm{H}_{2}\right)$ gas using a GC-MS, shown in the later section of Figure 9. In addition, a dendritic structure was also formed on the corroded Al surface, resulting in cracks on the Al surface, similar to the mud-crack-like surface morphology. The addition of a bimetallic contact $(\mathrm{Cu})$ on the Al surface helped the $\mathrm{Cl}^{-}$ions break down the passivation layer on $\mathrm{Al}$ more readily, coupled with $\mathrm{H}_{2}$ gas evolution, resulting in increased corrosion activity. As shown in Figure $6 \mathrm{~d}$, the Al surface was corroded entirely in only $8 \mathrm{~h}$ with bimetallic contact, compared with only minor corrosion observed on the Al blanket sample after $24 \mathrm{~h}$ (see Figure $2 \mathrm{~b}$ ).

In the $\mathrm{F}^{-}$corrosion study (see Figure 7 ), compared with $\mathrm{Cl}^{-}$, the $\mathrm{Al}$ corrosion morphology screened by $\mathrm{Cu}$ micropattern corrosion was entirely different. Al corrosion was highly concentrated around the $\mathrm{Cu} / \mathrm{Al}$ interface in the presence of $\mathrm{F}^{-}$ions. Additionally, corrosion was observed in the $\mathrm{Al}$ substrate between the $\mathrm{Cu}$ dots. A significant contrast was that compared with the $\mathrm{Cl}^{-}$corrosion mentioned earlier, no visible gas escape, dendrites, or mud cracks were seen in the $\mathrm{F}^{-}$corrosion. Even after $12 \mathrm{~h}$, the corrosion was limited to the $\mathrm{Cu} / \mathrm{Al}$ interface and $\mathrm{Al}$ area. The $\mathrm{Al}$ between the $\mathrm{Cu}$ dots showed some removal, as evidenced by the fading color change observed in Figure $7 \mathrm{~b}, \mathrm{~d}$ with minimal dendrite corrosion and no gas evolution. 

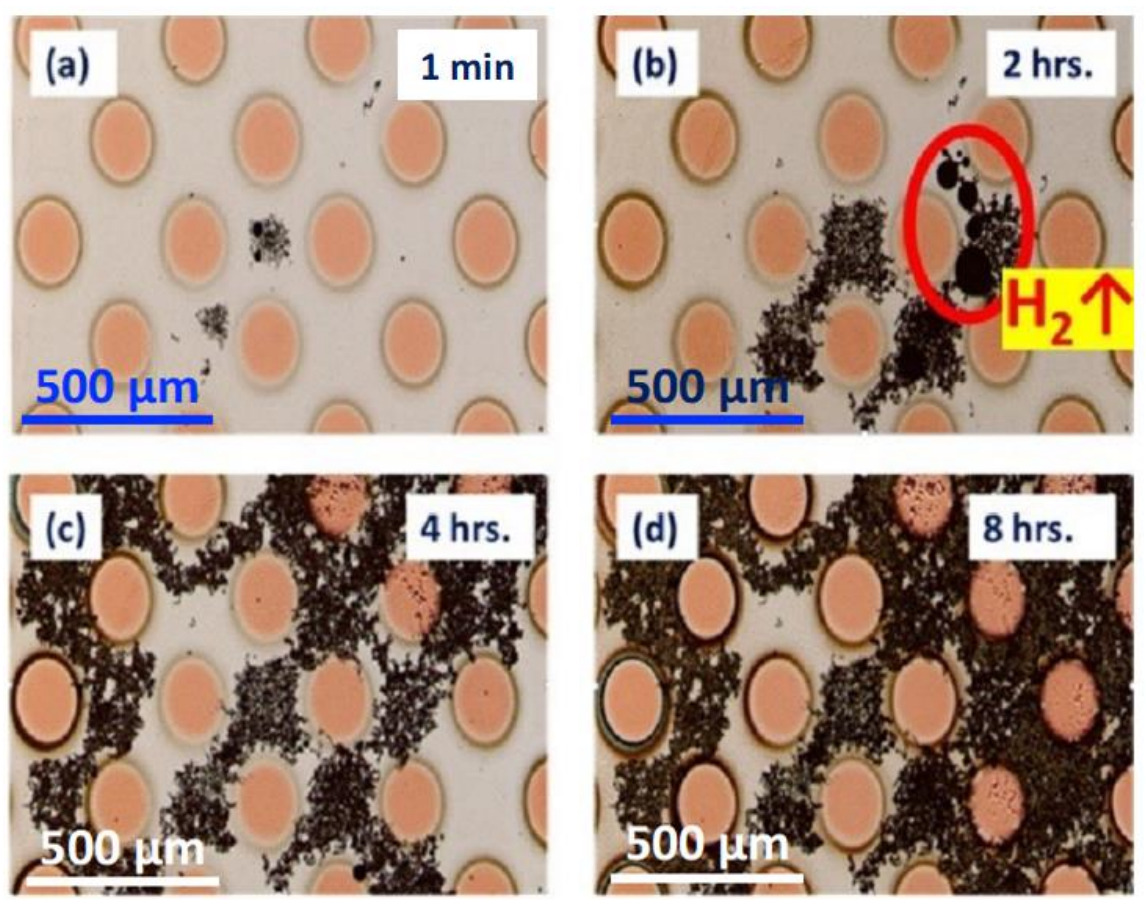

Figure 6. Micropattern corrosion screening of $\mathrm{Al} / \mathrm{Cu}$ bimetallic contact immersed in $5 \mathrm{ppm} \mathrm{Cl}^{-}$ solution at $\mathrm{pH}$ 5. The images were taken (a) soon after immersion (b); immersion time $=2 \mathrm{~h}$, (c) $4 \mathrm{~h}$, (d) $8 \mathrm{~h}$.
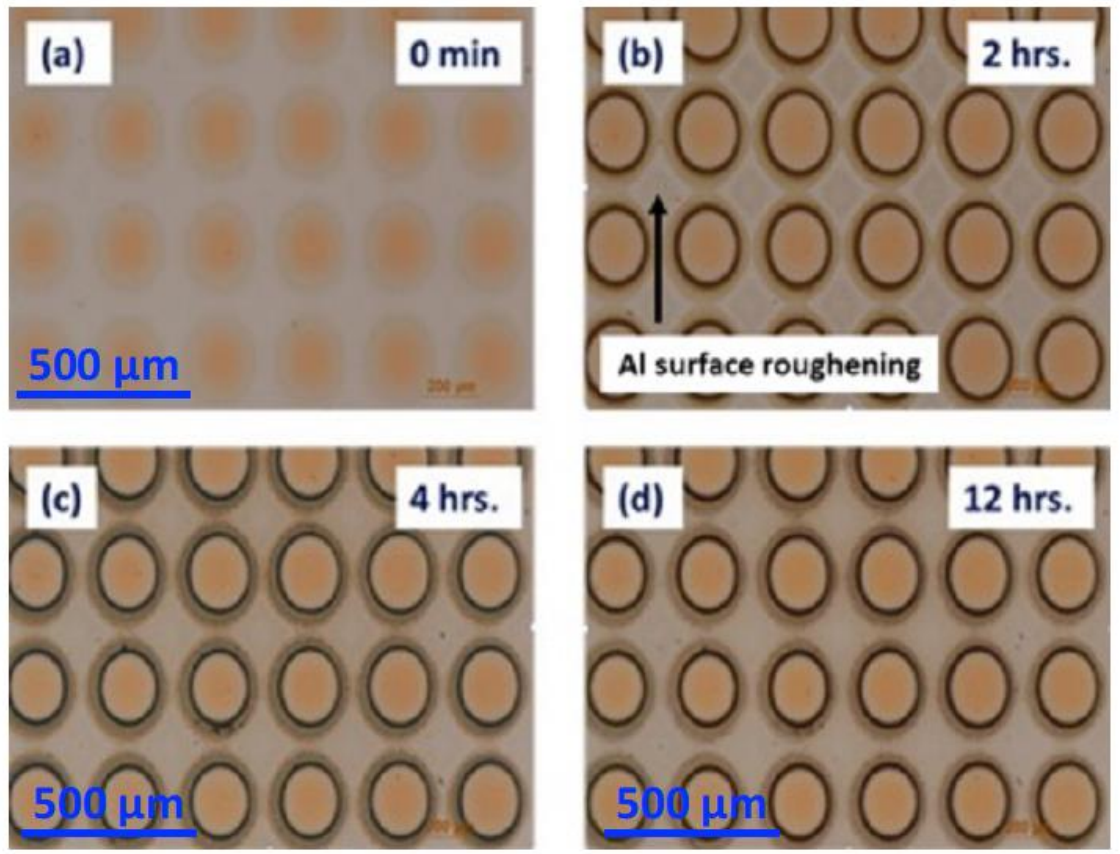

Figure 7. Micropattern corrosion screening of $\mathrm{Al} / \mathrm{Cu}$ bimetallic contact immersed in $5 \mathrm{ppm} \mathrm{F}^{-}$ solution at $\mathrm{pH}$ 5. The images were taken at (a) $0 \mathrm{~h}$ after immersion; (b) immersion time $=2 \mathrm{~h}$, (c) $4 \mathrm{~h}$, (d) $12 \mathrm{~h}$.

\subsubsection{SEM and EDS Investigation of the Corroded Micropattern Cu/Al Samples}

After $44 \mathrm{~h}$ of immersion in $5 \mathrm{ppm} \mathrm{Cl}^{-}$and $5 \mathrm{ppm} \mathrm{F}^{-}$, as shown in Figure 8, EDS analyses of the corroded samples revealed the difference in surface products between $\mathrm{Cl}^{-}-$and $\mathrm{F}^{-}$-immersed corrosion. The EDS spectrum of the severely corroded Al surface (Figure 8a) exposed to $5 \mathrm{ppm} \mathrm{Cl}^{-}$showed mostly $\mathrm{Al}$ and $\mathrm{O}$ signals that suggested dendrite 
formation, as the corrosion product was mainly $\mathrm{Al}(\mathrm{OH})_{3}$. In addition, the observed $\mathrm{H}_{2}$ gas evolution (Figure $6 \mathrm{~b}$ ) could generate high internal pressure to rupture and delaminate the $\mathrm{Al}$ film. This, in turn, caused more freshly exposed non-passivated Al metal to corrode and form more $\mathrm{Al}(\mathrm{OH})_{3}$ dendrites.
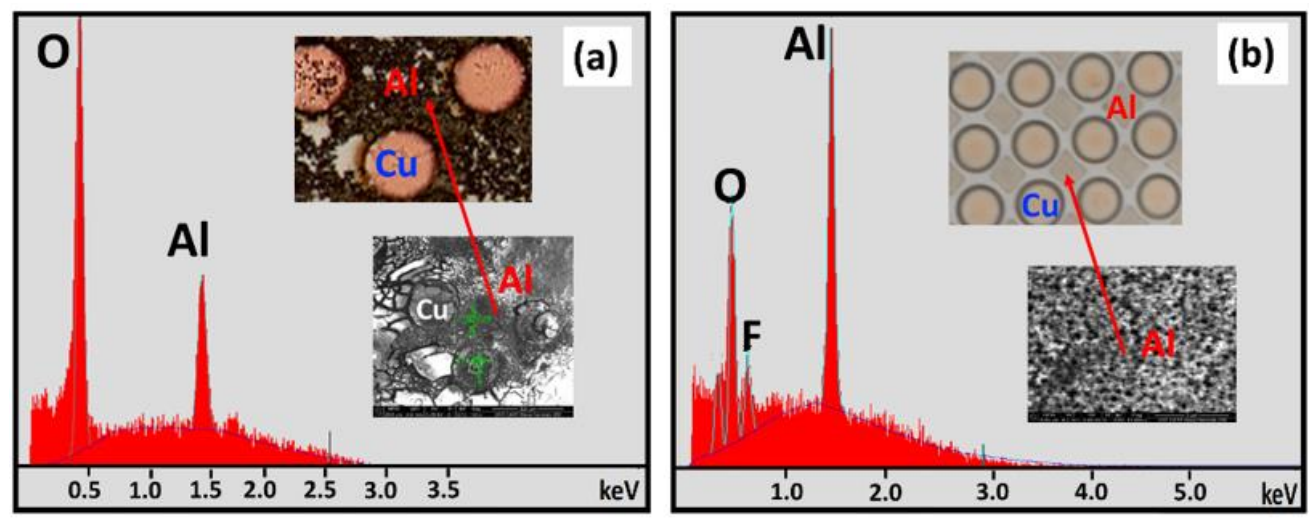

Figure 8. EDS analysis spectrum of corroded $\mathrm{Cu}$ microdot samples on $\mathrm{Al}$ after $44 \mathrm{~h}$ of immersion in (a) 5 ppm $\mathrm{Cl}^{-}, \mathrm{pH}$, and (b) $5 \mathrm{ppm} \mathrm{F}^{-}, \mathrm{pH} 5$ (inset: SEM and microscope image of the corroded samples).

In contrast, the EDS spectrum of $\mathrm{F}^{-}$-corroded samples, as shown in Figure 8b, revealed an $\mathrm{F}^{-}$signal in addition to $\mathrm{O}$ and $\mathrm{Al}$ signals, indicating that surface products such as $\mathrm{AlF}_{\mathrm{x}}$ and $\mathrm{AlOF}_{\mathrm{x}}$ could form on the Al surface. In addition, it was observed that the SEM image of the corroded $\mathrm{Al}$ surface became rough without any dendrites, similar to the situation observed in the surface corrosion of the $\mathrm{Al}$ substrate.

\subsubsection{GC-MS Investigation of the Gas Evolution in Microdot Samples}

The headspace chromatography analysis of gas evolved showed that under $\mathrm{Cu} / \mathrm{Al}$ bimetallic contact, $\mathrm{Cl}^{-}$contamination gave an extensive signal for $\mathrm{H}_{2}$ (Figure 9a), whereas a minimal $\mathrm{H}_{2}$ signal was observed for the $\mathrm{F}^{-}$case (Figure $9 \mathrm{~b}$ ) in comparison with the blank (Figure 9c). The GC-MS data confirmed our hypothesis and corroborated well with what we observed in $\mathrm{Cu}$ micropattern corrosion screening (Figures 6 and 7).
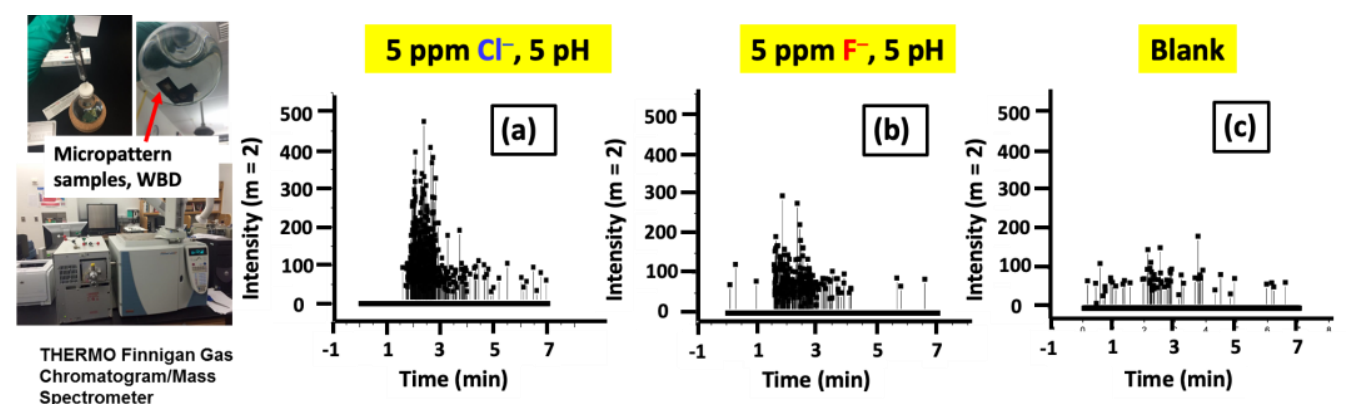

Figure 9. GC-MS analysis of $\mathrm{H}_{2}$ evolution in microdot samples immersed for $40 \mathrm{~h}$ in $5 \mathrm{ppm}$, pH 5 solutions showing (a) intense gas evolution signal in $\mathrm{Cl}^{-}$solution, (b) minimal gas evolution signal in $\mathrm{F}^{-}$solution, (c) blank signal without any gas evolution. 


\subsection{Halide-Induced Real-Time Corrosion Investigation of WBD}

The in situ WBD immersion monitoring of the corrosion morphology in real time matched the corrosion morphology observed in the simulated micropattern immersion screening. The WBD with $\mathrm{Cu}$ wire on the $\mathrm{Al}$ bonding pad was immersed in a $5 \mathrm{ppm}$ $\mathrm{Cl}^{-}, \mathrm{pH} 5$ solution. The real-time imaging showed rapid $\mathrm{H}_{2}$ gas escape, accompanied by rapid corrosion propagation with dendrite formation. Al bond pad corrosion extended underneath the $\mathrm{Cu}$ ball bond with the progress of time, causing the $\mathrm{Cu}$ wire to lift off from the $\mathrm{Al}$ pad. The corrosion screening data showed that even such low ppm levels of $\mathrm{Cl}^{-}$ concentration can result in aggressive $\mathrm{Al}$ pad corrosion, $\mathrm{Cu}$ bonding ball lift-off, and thus complete device failure in about $2 \mathrm{~h}$, as shown in Figure 10d and inset.
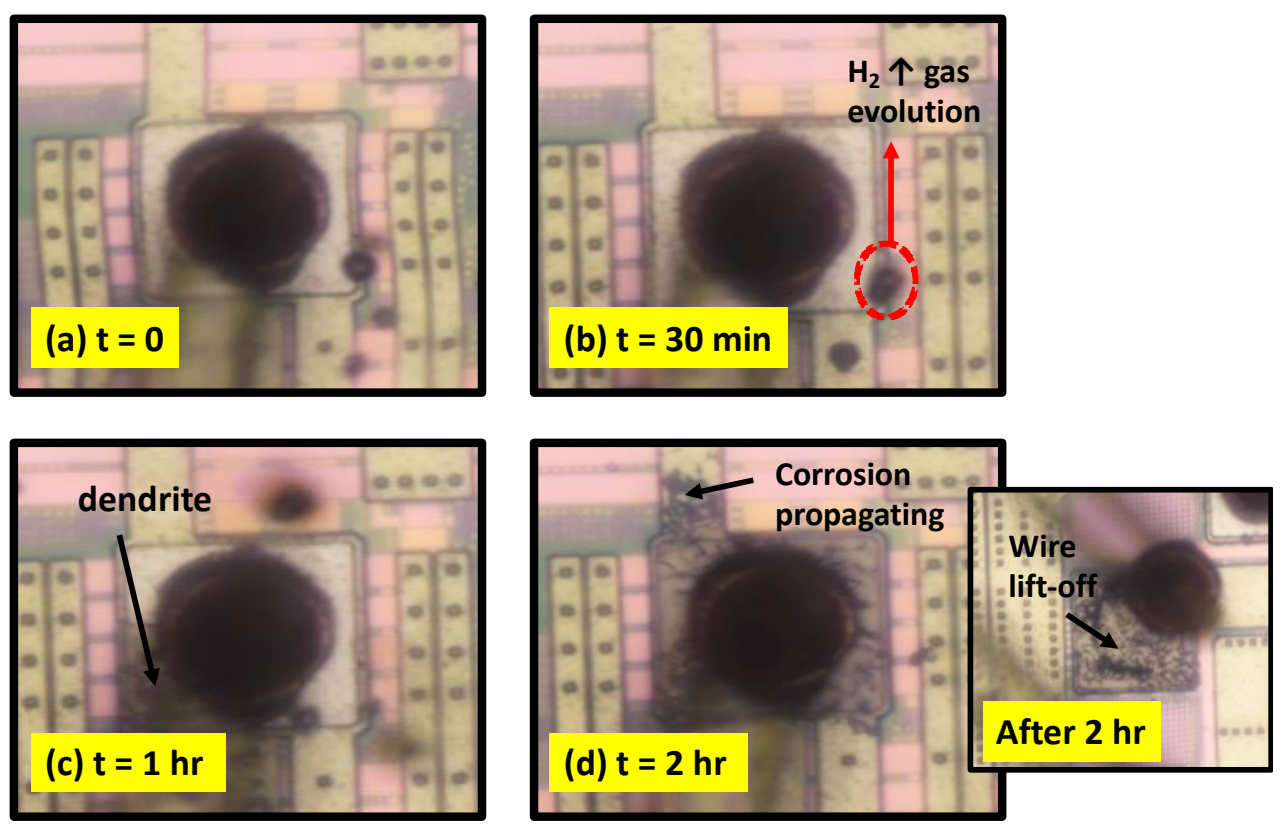

Figure 10. Real-time corrosion progression of $\mathrm{WBD}\left(\mathrm{Cu}\right.$ wire on $\mathrm{Al}$ bond pad) in $5 \mathrm{ppm} \mathrm{Cl}^{-}, \mathrm{pH} 5$ solution (a) immediately after immersion, (b) $\mathrm{H}_{2}$ evolution from $\mathrm{Cu} / \mathrm{Al}$ interface, (c) dendrite initiation and propagation, and (d) complete corrosion of $\mathrm{Al} \mathrm{pad}$, resulting in $\mathrm{Cu}$ wire lift-off (wire lift-off microscope image, inset).

Figure 11 shows the corrosion progress of WBD immersed in $5 \mathrm{ppm} \mathrm{F}^{-}$, $\mathrm{pH} 5$ solution, which is very similar to the corrosion of micropatterned samples observed in $\mathrm{F}^{-}$. Further in situ investigation showed $\mathrm{Al}$ pad complete corrosion visible from its color change, as shown in Figure 11b, in about $3 \mathrm{~h}$. Then the $\mathrm{Al}$ pad thin film was corroded entirely, revealing the underneath metallization layer, as shown in Figure 11c. The corrosion was then progressed by $\mathrm{F}^{-}$ion contaminants seeping underneath the wire to corrode the pad buried underneath the ball bond, leading to wire lift-off in about $27 \mathrm{~h}$. The wire lift-off in $\mathrm{F}^{-}$ corrosion was much slower than the $\mathrm{Cl}^{-}$corrosion, which can be attributed to the absence of rapid $\mathrm{H}_{2}$ evolution in the $\mathrm{F}^{-}$-induced $\mathrm{Al}$ corrosion process. The difference in corrosion morphology confirmed in blanket $\mathrm{Al}$, micropattern $\mathrm{Cu}$ dot on $\mathrm{Al}$, and $\mathrm{WBD}$ between $\mathrm{Cl}^{-}$ and $\mathrm{F}^{-}$establishes that the mechanism of these contaminants is utterly different in their attacking nature towards the $\mathrm{Al}$ surface. 

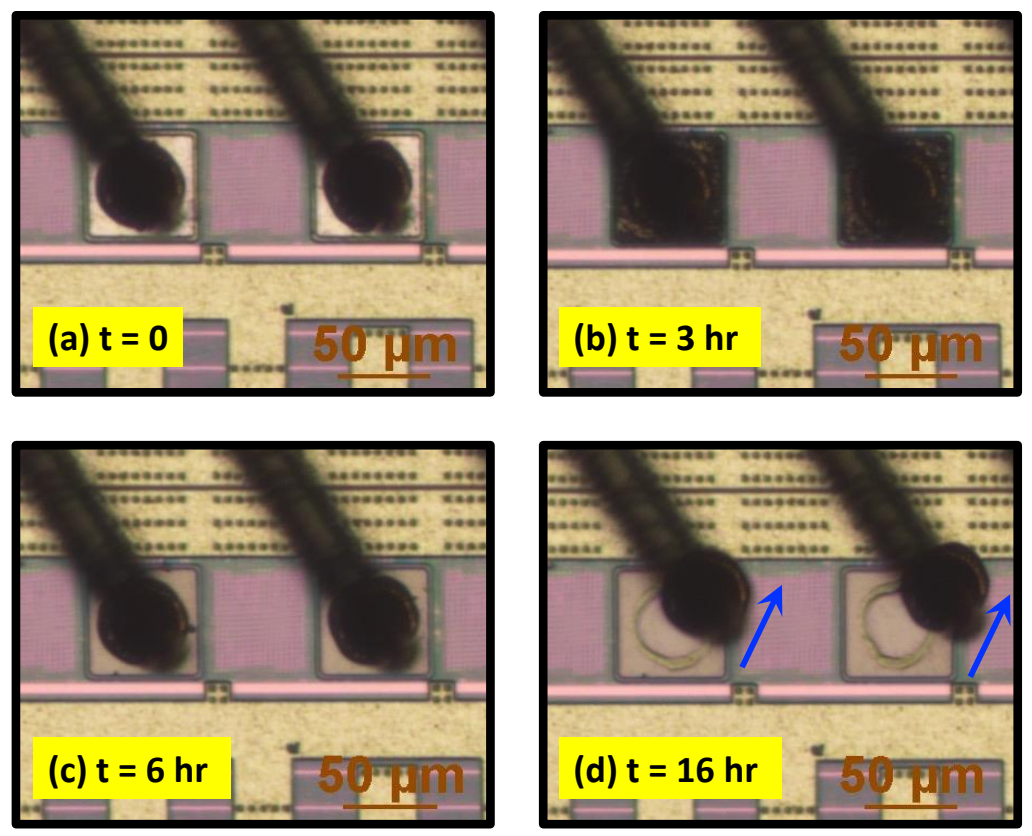

Figure 11. Real-time corrosion progression of $\mathrm{WBD}$ ( $\mathrm{Cu}$ wire on $\mathrm{Al}$ bond pad) in 5 ppm $\mathrm{F}^{-}$, $\mathrm{pH} 5$ solution (a) immediately after immersion; (b) Al pad completely corroded in about $3 \mathrm{~h}$; (c) $\mathrm{Al}$ pad completely removed, revealing the underneath layer; and (d) $\mathrm{Cu}$ bonding ball lift-off, revealing no Al left on the bonded region.

XPS Analysis of the Corroded Al Bond Pad

As shown in Figure 12, XPS analysis of the 3 h corroded WBD (see Figure 10b) with the $\mathrm{F}^{-}$surface products on $\mathrm{Al}$ was carried out to identify its bonding chemistry. The XPS spectrum in the region of the F-1s signal on the corroded black region was deconvoluted due to the presence of a shoulder, which showed the central peak at $687.4 \mathrm{eV}$ corresponding to $\mathrm{AlF}_{3}$ species present on the surface and the secondary peak at $685.8 \mathrm{eV}$ related to the presence of aluminum oxyfluoride species (Figure 12a) [19]. The Al 2p spectrum investigation revealed a prominent peak of $77.0 \mathrm{eV}$ after the deconvolution, confirming $\mathrm{AlF}_{3}$ surface products as the main species during corrosion along with some Al-hydroxy-F species seen from the secondary peak observed at $75.8 \mathrm{eV}$, as shown in Figure 12b [20]. The additional green spectra observed with a peak at $689 \mathrm{eV}$ and $74.6 \mathrm{eV}$ corresponded to the organic fluorides, and the brown spectra observed with a peak at $73.8 \mathrm{eV}$ corresponded to Al-O species on the corroded surface [21].

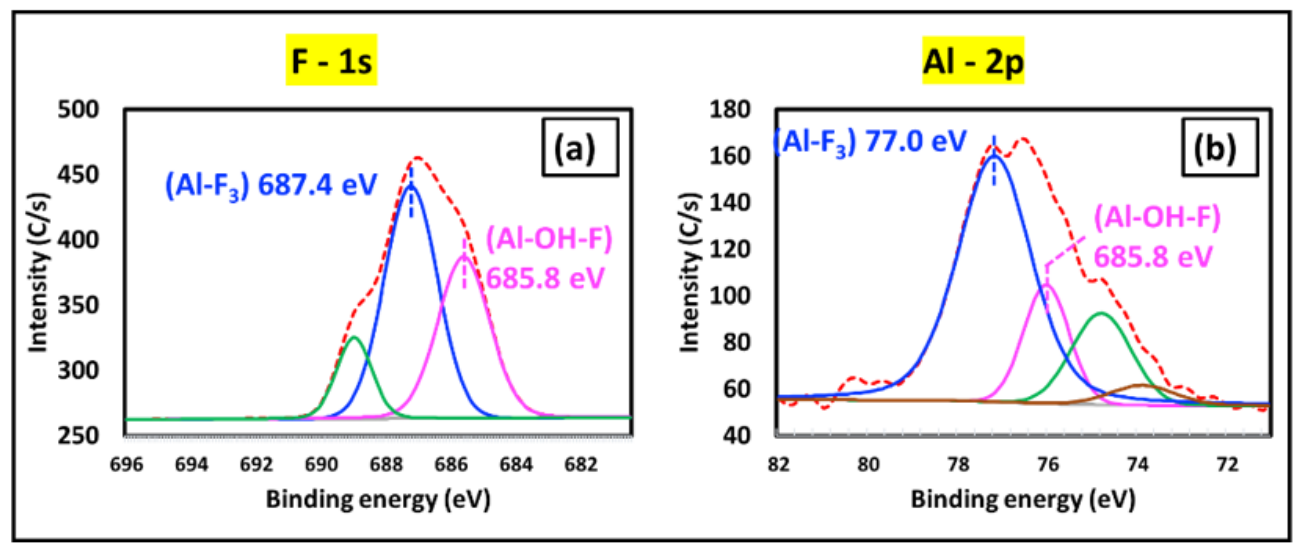

Figure 12. (a) F-1s core level and (b) Al 2p core level X-ray photoelectron spectra of the corroded Al pad immersed in $5 \mathrm{ppm} \mathrm{F}^{-}, \mathrm{pH} 5$ solution after $3 \mathrm{~h}$ (red dotted lines reveal the original spectra before deconvolution). 


\section{Discussion}

Corrosion Mechanism Comparison of $\mathrm{Cl}^{-}$vs. $\mathrm{F}^{-}$

Visual investigation of the corroded blanket $\mathrm{Al}$ surface showed more vigorous pitting and mud crack corrosion in $\mathrm{F}^{-}$solution than in $\mathrm{Cl}^{-}$solution, which only showed mild pitting and surface roughening. The stark difference in this extent of attack between $\mathrm{Cl}^{-}$ and $\mathrm{F}^{-}$, as shown in Figure 2, can come from two main reasons. First, $\mathrm{F}^{-}$, being a stronger base than $\mathrm{Cl}^{-}$, can attack the positively surface-charged oxide layer in solution more readily due to a stronger acid-base interaction. Second, Al surface oxide is well known to form a series of complexes with $\mathrm{F}^{-}$ions ranging from $\mathrm{AlF}^{2+}$ to $\mathrm{AlF}_{6}{ }^{3-}$ [22] and reported literature shows that the adsorption of $\mathrm{F}^{-}$by $\mathrm{Al}$ oxide is maximum at $\mathrm{pH} 5$ [23]. The EDS analyses of the corroded $\mathrm{Al}$ surface revealed a key difference in corrosion products (see Table 1). The mud crack islands seen in $\mathrm{Cl}^{-}$samples did not have any measurable $\mathrm{Cl}^{-}$signal, whereas a strong signal for $\mathrm{F}^{-}$was observed on $\mathrm{Al}$ samples corroded in $\mathrm{F}^{-}$solutions. In the case of $\mathrm{Cl}^{-}$, we propose that $\mathrm{Al}$ corrodes to give $\mathrm{AlCl}_{3}$ as the primary corrosion product. The high solubility of $\mathrm{AlCl}_{3}\left(460 \mathrm{~g} / \mathrm{L} @ 30^{\circ} \mathrm{C}\right)$ in aqueous solutions [24] results in the formation of $\mathrm{Al}(\mathrm{OH})_{3}$ via hydrolysis. The EDS of mud cracks from $\mathrm{Cl}^{-}$corrosion agrees well with this statement as it only has $\mathrm{Al}$ and $\mathrm{O}$ signals, and no $\mathrm{Cl}^{-}$signal was observed. However, that is not the case with $\mathrm{F}^{-}$corrosion. The primary corrosion product proposed in this case would be aluminum trifluoride $\left(\mathrm{AlF}_{3}\right)$, a relatively poorly soluble compound $(0.0053 \mathrm{~g} / \mathrm{L}$ (a $20^{\circ} \mathrm{C}$ ) in aqueous solution [25]. Due to this fact, an intense $\mathrm{F}^{-}$signal was seen in the EDS analysis, suggesting the presence of insoluble Al-F species formed due to corrosion. In addition to this insoluble Al-F species, some other more soluble species, such as $\mathrm{Al}-(\mathrm{OH})-\mathrm{F}$ species, could be forming on the Al samples' surface [26]. Therefore, in the absence of $\mathrm{Cu} / \mathrm{Al}$ bimetallic contact, SEM and EDS showed that $\mathrm{F}^{-}$contaminant produced more aggressive pitting corrosion than $\mathrm{Cl}^{-}$.

Separated in the galvanic series, $\mathrm{Cu}$ and $\mathrm{Al}$ had almost $+2.0 \mathrm{~V}$ difference in their standard reduction potential [27]. Cu on bimetallic contact with $\mathrm{Al}$ in the presence of $\mathrm{Cl}^{-}$showed a different and faster corrosion progression morphology on $\mathrm{Al}$, as shown in Figure 6 compared with Figure 2b. In the $\mathrm{Cl}^{-}$condition, this aggressive corrosion was due to the potential difference that thermodynamically accelerated the Al oxidative dissolution by $\mathrm{Cl}^{-}$ions, leading to the formation of $\mathrm{AlCl}_{3}$. The hydrolysis of this more soluble $\mathrm{AlCl}_{3}$ product created local acidity (as protons) on the Al surface (Equation (3)). The $\mathrm{Cu}$ surface, acting as the cathode in this galvanic couple, functioned as a suitable site for reducing protons to produce $\mathrm{H}_{2}$ evolution (Equation (4)) and was experimentally observed in Figure $6 \mathrm{~b}$ or Figure 10b. Hydrogen evolution was previously reported as a possible cathodic reaction in a $\mathrm{Cu} / \mathrm{Al}$ galvanic system [28]. This $\mathrm{H}_{2}$ evolution with rapid volume expansion can create aggressive erosion effects on the $\mathrm{Al}$ substrate to form deep corrosion cracks, pits, and dendrites [29]. The detailed mechanism of this $\mathrm{Cl}^{-}$corrosion on $\mathrm{Cu} / \mathrm{Al}$ peripheral bimetallic contact in WBD was previously reported by Ross et al. [16].

$$
\begin{gathered}
\mathrm{Al} \rightarrow \mathrm{Al}^{3+}+3 \mathrm{e}^{-} \\
\mathrm{Al}^{3+}+3 \mathrm{Cl}^{-} \rightarrow \mathrm{AlCl}_{3} \\
\mathrm{AlCl}_{3}+3 \mathrm{H}_{2} \mathrm{O} \rightarrow \mathrm{Al}(\mathrm{OH})_{3}+3 \mathrm{H}^{+}+3 \mathrm{Cl}^{-} \\
3 \mathrm{H}^{+}+3 \mathrm{e}^{-} \rightarrow \frac{3}{2} \mathrm{H}_{2} \uparrow
\end{gathered}
$$

In the $\mathrm{F}^{-}$case, the corrosion morphology observed in $\mathrm{Cu} / \mathrm{Al}$ bimetallic contact samples, as shown in Figures 7 and 11, was similar to the corrosion in blanket $\mathrm{Al}$ (Figure 2c). As observed in Figure 11, no dendrite or $\mathrm{H}_{2}$ evolution was visibly observed; instead, $\mathrm{Al}$ dissolution was observed by forming significant surface product $\mathrm{AlF}_{3}$, as confirmed by XPS, as shown in Figure 12. The $\mathrm{AlF}_{3}$ product was slowly removed from the surface, revealing the underneath layer observed in Figure 12b. The mechanism of $\mathrm{F}^{-}$corrosion was similar with and without the presence of bimetallic contact mainly due to this formation of this 
poorly soluble $\mathrm{AlF}_{3}$ corrosion product that cannot be easily hydrolyzed and removed like $\mathrm{AlCl}_{3}$. Therefore, the creation of the local high acidity became difficult, as proposed in Equation (3), and hence, the cathodic reaction of $\mathrm{H}_{2}$ evolution was greatly reduced in the $\mathrm{F}^{-}$condition.

In summary, the $\mathrm{Cl}^{-}$-induced corrosion in WBD is a highly efficient electrochemical corrosion process, driven by $\mathrm{Cu} / \mathrm{Al}$ bimetallic contact, with rapid removal of the corroded product, $\mathrm{Al}(\mathrm{OH})_{3}$ dendrites, and reduction product of the active $\mathrm{H}_{2}$ evolution. In contrast, the $\mathrm{F}^{-}$corrosion process has a rate-determined step of slower dissolution reaction of $\mathrm{Al}$ to $\mathrm{AlF}_{3}$, as confirmed by XPS analysis on WBD (Figure 12a). Consequently, the smaller amount of $\mathrm{H}_{2}$ gas observed in GC-MS (Figure $9 b$ ) and the less soluble nature of intermediates, such as $\mathrm{Al}(\mathrm{OH})_{\mathrm{x}}(\mathrm{F})_{\mathrm{y}}$, as suggested by the XPS analysis (Figure 12), further slowdown the overall $\mathrm{F}^{-}$-induced corrosion on $\mathrm{Al}$ pads of $\mathrm{Cu}$ WBD.

For $\mathrm{Cl}^{-}$corrosion, the potential prevention strategy proposed is to halt the $\mathrm{H}_{2}$ evolution (cathodic reaction) by using an azole-based $\mathrm{Cu}$-selective inhibitor to eliminate the galvanic contact, thereby preventing the redox corrosion process. A copper (cathode)specific azole inhibitor was applied to the $\mathrm{Cu}$ wire, and the device was subjected to the same $\mathrm{Cl}^{-}$corrosion condition. Figure 13a shows that the $\mathrm{Cu}$ selective inhibitor completely prevented $\mathrm{H}_{2}$ gas evolution and inhibited corrosion dendrite formation on the $\mathrm{Al}$ bond pads. Contrastingly, $\mathrm{F}^{-}$, as a stronger etchant to the $\mathrm{Al}$ pad, leading to the formation of a less soluble $\mathrm{AlF}_{3}$, received no protection from the same $\mathrm{Cu}$-selective inhibitor, as shown in Figure 13b. This mechanistic investigation gave us key insight in identifying the difference in mechanism between the two halide contaminants and highlighted the need for further development of Al-specific inhibitors to protect WBDs from $\mathrm{F}^{-}$corrosion.
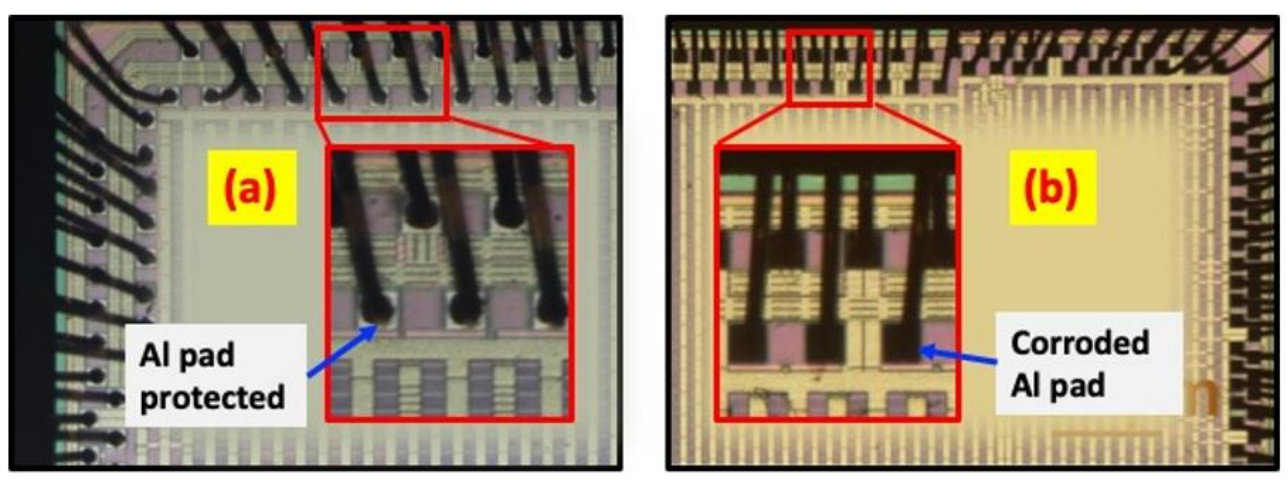

Figure 13. Copper-specific inhibitor coated to WBD immersed in (a) $5 \mathrm{ppm} \mathrm{Cl}^{-}, \mathrm{pH} 5$ solution for more than $24 \mathrm{~h}$ showing $\mathrm{Al}$ pad protection and no $\mathrm{Cu}$ wire lift-off (inset: zoomed-in image of $\mathrm{Al}$ bond pad region remaining protected) and (b) $5 \mathrm{ppm} \mathrm{F}^{-}, \mathrm{pH} 5$ solution for more than $24 \mathrm{~h}$ showing complete corrosion of $\mathrm{Al}$ bond pad (inset: zoomed-in image of $\mathrm{Al}$ bond pad region corroded).

\section{Conclusions}

The corrosion morphology and mechanism of $\mathrm{Al}$ corrosion in $\mathrm{Cl}^{-}$and $\mathrm{F}^{-}$were compared in the $5 \mathrm{ppm}$ level contaminations at $\mathrm{pH}$. Al was found to corrode very differently with and without bimetallic contact. The nature and solubility of the proposed corrosion product $\left(\mathrm{AlCl}_{3} \mathrm{vs}\right.$. $\left.\mathrm{AlF}_{3}\right)$ were found to influence the corrosion morphology, corrosion products, and sustaining corrosion progression. In addition, $\mathrm{H}_{2}$ evolution was observed extensively only in $\mathrm{Cl}^{-}$-induced $\mathrm{Al}$ corrosion aided by bimetallic contact. The obtained mechanistic insights using $\mathrm{Cu}$ micropattern corrosion screening could be beneficial in exploring the $\mathrm{Al}$ bond pad corrosion in $\mathrm{Cu}$ wire-bonded devices. Research is ongoing to test $\mathrm{Al}$ corrosion prevention mechanisms in real-life $\mathrm{Cu}$ wire-bonded devices to formulate preventive measures further to mitigate halide-induced corrosion. While stopping the electrochemical reaction can solve the corrosion of $\mathrm{Al}_{\text {in }} \mathrm{Cl}^{-}$environment under $\mathrm{Cu} / \mathrm{Al}$ bimetallic influence, the same would not help in preventing corrosion caused 
by $\mathrm{F}^{-}$ions as it is much more of a dissolution reaction and proceeds similarly in the presence and absence of $\mathrm{Cu} / \mathrm{Al}$ bimetallic contact.

Author Contributions: Methodology, data curation, investigation, writing-original draft preparation, G.I.A.K.; data curation, investigation, visualization, A.L.; data curation, investigation, writingreview and editing, software, J.C.; investigation, visualization, writing - review, and editing, M.A.; investigation, W.Y.; conceptualization, supervision, project administration, funding acquisition, resources, O.C. All authors have read and agreed to the published version of the manuscript.

Funding: The authors gratefully acknowledge the financial supports from SRC (GRC 2665.001) and the University of North Texas for this study.

Institutional Review Board Statement: Not applicable.

Informed Consent Statement: Not applicable.

Data Availability Statement: The data presented in this study are available on request from the corresponding author. The data are not publicly available due to usage of WBD obtained from industrial collaborators, which can reveal their design patterns.

Acknowledgments: O.C. would like to thank Varughese Mathew for the helpful discussion and assistance. O.C. also acknowledges the UNT Materials Research Facility (MRF) for providing SEM/EDS characterization assistance. The authors acknowledge the UNT Chemistry Departmental Instrumentation Laboratory and Jose Calderon for the assistance in GC-MS.

Conflicts of Interest: The authors declare that they have no known competing financial interests or personal relationships that could have appeared to influence the work reported in this paper.

\section{References}

1. Gan, C.L.; Hashim, U. Evolutions of bonding wires used in semiconductor electronics: Perspective over 25 years. J. Mater. Sci. Mater. Electron. 2015, 26, 4412-4424. [CrossRef]

2. Liu, D.; Chen, H.; Wu, J.; Then, E. Corrosion Behavior of Cu-Al Intermetallic Compounds in Copper Wire Bonding in ChlorideContaining Accelerated Humidity Testing. In Proceedings of the 2016 IEEE 66th Electronic Components and Technology Conference (ECTC), Las Vegas, NV, USA, 31 May-3 June 2016; pp. 629-636. [CrossRef]

3. $\mathrm{Fu}, \mathrm{S}$.-W.; Lee, C.C. A corrosion study of $\mathrm{Ag}-\mathrm{Al}$ intermetallic compounds in chlorine-containing epoxy molding compounds. J. Mater. Sci. Mater. Electron. 2017, 28, 15739-15747. [CrossRef]

4. Yang, Y.; Zhu, X.; Nistala, R.R.; Zhao, S.; Xu, J. A method to simulate fluorine outgas and Al bond pad corrosion in wafer fab. In Proceedings of the 2016 IEEE 23rd International Symposium on the Physical and Failure Analysis of Integrated Circuits (IPFA), Singapore, 18-21 July 2016; pp. 340-343. [CrossRef]

5. Younan, H.; Xiang, X.Z.; Xiaomin, L. Characterization studies of fluorine-induced corrosion crystal defects on microchip Al bondpads using X-ray photoelectron spectroscopy. In Proceedings of the 2014 IEEE 21th International Symposium on the Physical and Failure Analysis of Integrated Circuits (IPFA), Singapore, 30 June-4 July 2014; pp. 90-93. [CrossRef]

6. Song, M.; Mathew, V.; Li, L.; Wang, S.; Han, M.C.; Song, Y.; Descartin, A.M. A New Finding of Cu-Al IMC Corrosion and Investigation of Fluorine Contamination Influence on $\mathrm{Cu}-\mathrm{Al}$ IMC Corrosion. In Proceedings of the 20th International Conference on Electronic Packaging Technology (ICEPT), Hong Kong, China, 11-15 August 2019; pp. 1-4. [CrossRef]

7. Farrah, H.; Slavek, J.; Pickering, W. Fluoride interactions with hydrous aluminum oxides and alumina. Soil Res. 1987, 25, 55-69. [CrossRef]

8. Proost, J.; Baklanov, M.; Verbeeck, R.; Maex, K. Morphology of corrosion pits in aluminum thin film metallizations. J. Solid State Electrochem. 1998, 2, 150-155. [CrossRef]

9. Loto, R.T. Investigation of the Localized Corrosion Resistance of 4044 Aluminum Alloy in Acid Chloride and Neutral Chloride Solutions. J. Fail. Anal. Prev. 2018, 18, 905-911. [CrossRef]

10. Lall, P.; Luo, Y.; Nguyen, L. Chlorine-Ion Related Corrosion in Cu-Al Wirebond Microelectronic Packages. In International Electronic Packaging Technical Conference and Exhibition; American Society of Mechanical Engineers: New York, NY, USA, 2015; p. V002T02A012. [CrossRef]

11. Mathew, V.; Wikramanayake, E.; Chopin, S.F. Corrosion of Copper Wire bonded Packages by Chlorine Containing Foreign Particles. In Proceedings of the 2020 IEEE 70th Electronic Components and Technology Conference (ECTC), Lake Buena Vista, FL, USA; 2020; pp. 504-511. [CrossRef]

12. Liao, L.J.; Zhang, X.; Li, X.; Hua, Y.; Fu, C.; Tee, W.; Yee, B.; Wang, B.; Mao, S. Comprehensive study of wire bond reliability impacts from wire, molding compound and bond pad contamination. In Proceedings of the 17th IEEE International Conference on IC Design and Technology (ICICDT), Suzhou, China, 17-19 June 2019. [CrossRef]

13. Uno, T. Bond reliability under humid environment for coated copper wire and bare copper wire. Microelectron. Reliab. 2011, 51, 148-156. [CrossRef] 
14. Chauhan, P.; Zhong, Z.W.; Pecht, M. Copper Wire Bonding Concerns and Best Practices. J. Electron. Mater. 2013, 42, 2415-2434. [CrossRef]

15. Zeng, Y.; Bai, K.; Jin, H. Thermodynamic study on the corrosion mechanism of copper wire bonding. Microelectron. Reliab. 2013, 53, 985-1001. [CrossRef]

16. Ross, N.; Asokan, M.; Kumar, G.I.A.; Caperton, J.; Alptekin, J.; Salunke, A.S.; Chyan, O.M. Mechanistic study of copper wire-bonding failures on packaging devices in acidic chloride environments. Microelectron. Reliab. 2020, 113, 113917. [CrossRef]

17. Kumar, G.I.A.; Alptekin, J.; Caperton, J.; Salunke, A.; Chyan, O. Accelerated reliability testing of Cu-Al bimetallic contact by a micropattern corrosion testing platform for wire bond device application. MethodsX 2021, 8, 101320. [CrossRef]

18. Semiconductor Epoxy Mold Compounds. Available online: https://www.caplinq.com/semiconductor-epoxy-mold-compounds. $\mathrm{html}$ (accessed on 10 June 2021).

19. Moreno-López, J.C.; Ruano, G.; Ferrón, J.; Ayala, P.; Passeggi, M.C.G. Thermally Annealed Sub-Monolayers of AlF 3 on Cu(100): An STM and XPS Study. Phys. Status Solidi B 2018, 255, 1800389. [CrossRef]

20. Chastain, J.; Moulder, J.F. Handbook of X-ray Photoelectron Spectroscopy: A Reference Book of Standard Spectra for Identification and Interpretation of Xps Data; Physical Electronics Inc.: Eden Prairie, MN, USA, 1995; pp. 230-232, ISBN 0-9648124-1-X.

21. Roodenko, K.; Halls, M.; Gogte, Y.; Seitz, O.; Veyan, J.-F.; Chabal, Y.J. Nature of Hydrophilic Aluminum Fluoride and Oxyaluminum Fluoride Surfaces Resulting from $\mathrm{XeF}_{2}$ Treatment of $\mathrm{Al}$ and $\mathrm{A}_{12} \mathrm{O}_{3}$. J. Phys. Chem. C 2011, 115, 21351-21357. [CrossRef]

22. Xue, T.; Cooper, W.C.; Pascual, R.; Saimoto, S. Effect of fluoride ions on the corrosion of aluminium in sulphuric acid and zinc electrolyte. J. Appl. Electrochem. 1991, 21, 238-246. [CrossRef]

23. Tang, Y.; Guan, X.; Su, T.; Gao, N.; Wang, J. Fluoride adsorption onto activated alumina: Modeling the effects of pH and some competing ions. Colloids Surf. A Physicochem. Eng. Asp. 2009, 337, 33-38. [CrossRef]

24. Seidell, A. Solubilities of Inorganic and Organic Compounds, 2nd ed.; D Van Nostrand Company: New York, NY, USA, 1919 ; p. 25.

25. Millipore Sigma. Safety Data Sheet. Available online: https://www.sigmaaldrich.com/US/en/sds/SIGMA/A8205 (accessed on 16 June 2021).

26. Cowley, J.M.; Scott, T.R. Basic Fluorides of Aluminum. J. Am. Chem. Soc. 1948, 70, 105-109. [CrossRef]

27. Atkins, P.; Paula, J. Chemical Equilibrium: Electrochemistry. In Elements of Physical Chemistry, 5th ed.; Oxford University Press: New York, NY, USA, 2009; Chapter 9, p. 212.

28. Curioni, M.; Scenini, F. The Mechanism of Hydrogen Evolution During Anodic Polarization of Aluminium. Electrochim. Acta 2015, 180, 712-721. [CrossRef]

29. Vrublevsky, I.; Parkoun, V.; Sokol, V.; Schreckenbach, J.; Marx, G. The study of the volume expansion of aluminum during porous oxide formation at galvanostatic regime. Appl. Surf. Sci. 2004, 222, 215-225. [CrossRef] 